\title{
English Subordinators in Finite Clause: Definition and Classification
}

\author{
Yali Liu ${ }^{1}$ \\ ${ }^{1}$ Department of Foundation, Northeast Petroleum University, QinHuangDao Campus, HeBei Province, China \\ Correspondence: Yali Liu, Department of Foundation, Northeast Petroleum University, QinHuangDao Campus, \\ 550 HeBei Street West, HaiGang District, QinHuangDao City, HeBei Province, 066004, China. Tel: \\ 86-185-1150-5630. E-mail: askabanimp@163.com
}

\author{
Received: March 19, 2014 Accepted: May 5, 2014 Online Published: July 30, 2014 \\ doi: 10.5539/ijel.v4n4p55 URL: http://dx.doi.org/10.5539/ijel.v4n4p55
}

\begin{abstract}
Traditional English grammar is still not clear on how to define and classify subordinators for finite clauses in that grammarians mix up relative clauses, which are dependent on NPs, and subordinate clauses, which are dependent on other clauses. And different functions of the markers of subordinate clauses are not fully investigated.

The author of this aritcle found, through comparative studies, that relative clauses should be distinguished from subordinate clauses, which implies that words introducing relative clauses are not subordinators, and even among the markers of subordinate clauses some of them, such as before, because and if that indicates condition, are actually prepositions. There leaves a small class of subordinators for finite clauses, namely, that, whether and if that indicates interrogation.
\end{abstract}

Keywords: subordinator, subordinate clause, preposition

\section{Introduction}

\subsection{Focus and Importance}

There is little doubt that defining various word classes is of great significance in facilitating teaching and learning English grammar. A clear definition of a word class in terms of form and syntactic function would enable students to learn how to use a certain class of words more accurately and is helpful to both teachers and students.

This paper talks mainly about subordinators, the definition and the classification. Grammarians disagree on what members should be included and how they should be classified, from the perspectives of form, meaning or function.

\subsection{Relevant Research}

Some grammarians, such as Quirk et al. (1985), Martin (2000), Downing and Locke (2002) and Carter and McCarthy (2006) define subordinators as markers of dependent status of clauses. However, Biber et al. (2000), Huddleston and Pullum (2005) think that subordinators are words which introduce subordinate clauses and serve to mark a clause as subordinate, which means that the indicators marking other types of subordination than subordinating clauses are not subordinators. To make the definition clearer the following questions have to be solved: does dependent status of clauses mean subordinate clauses? Do subordinators mark subordination including subordinate clauses or only subordinate clauses? What are the subordinate clauses? Do all markers of subordinate clauses function the same?

Quirk et al. (1985) and Carter and McCarthy (2006) divide subordinators into simple and complex subordinators in terms of form and Quirk et al.(1985) add correlative and marginal subordinators. Are simple subordinators single words and complex subordinators multi-word ones? Biber et al. (2000) identify major, complex and correlative subordinators without giving the standard by which a subordinator is viewed as major. Downing and Locke (2002) use simple conjunctions, conjunctive groups and complex conjunctions. What are the differences between the above classifications?

Subordinators are also divided in terms of meaning. Martin (2000) list time, place, reason, manner, contrast condition, purpose and result. Downing and Locke (2002) use time, contingency and manner etc.. And they both sub-classify time subordinators with quite different terms. 
Whereas Huddleston and Pullum (2005), from the perspective of function, pick out those subordinators that behave like prepositions and put them into the preposition class and thus extend the preposition class and leave three to the subordinators-that, whether and if that indicates interrogation. Biber et al. (2000) also use the term of complementizer, which emphasizes the syntactic function of marking complements and make distinctions between subordinators and relativizers.

The problems in classification might come from the different definitions above and also involve the various perspectives of classification. Which of them is more complete and reasonable?

\subsection{Approaches}

The approaches employed to solve the above mentioned questions are, firstly, to differentiate different kinds of subordination of clauses through comparison of the definitions made by some grammarians to clarify what subordinate clauses are. Then examine markers of subordinate clauses to see if they are different in terms of function. If yes, make out which of them should be put into the subordinator class and what classes the other markers belong to. At last the definition and classification of subordinators for finite clauses are given.

\section{Literature Review}

Grammarians, such as Quirk et al. (1985), Downing and Locke (2002), Carter and McCarthy (2006), Martin (2000), etc., agree that subordination of clauses means dependency of clauses on other constructions, in opposition to coordination and subordinators are markers of subordinating status of clauses.

However, they adopt different ways to classify subordinators. Some grammarians, such as Carter and McCarthy (2006), Quirk et al. (1985), etc., describe subordinators in terms of form; others, such as Martin (2000), in terms of meaning; Huddleston and Pullum (2005) divide subordinators from the perspective of syntactic function; still others, such as Biber et al. (2000), Downing and Locke (2002) include form, meaning and/or syntactic function.

Carter and McCarthy (2006) subdivide subordinators into simple and complex. Simple subordinators are single words which introduce subordinate clause; complex subordinators consist of more than one word and include common expressions ending in as and that (or optional that), plus a small number of other expressions (see Table 1 below).

Table 1.

\begin{tabular}{cc}
\hline simple & complex \\
\hline after, although, as, because, before, for, how, & as far as, as if, as/so long as, as soon as, as though, assuming \\
however, if, in case, in order that, lest, once, & (that), considering, given (that), granted (that), in case, in \\
since, that, though, till, unless, until, when, & order for, in order that, insofar as, insomuch as, in the event \\
whenever, where, whereas, wherever, which, & that, providing/provided (that), seeing as, seeing (that), such \\
while, whilst, who, whoever, whom, whose & that, supposing (that) \\
\hline
\end{tabular}

(Carter \& McCarthy, 2006, p. 558)

It should be said that this standard for classification is neat enough: if a subordinator contains only one word it is a simple subordinator. If not, complex subordinator. But they include in order that in the simple subordinators, which obviously goes against the standard they mentioned. In addition, the labels of simple and complex subordinators can't provide the learners with any clue on the usage of subordinators.

Quirk et al. (1985) made a more inclusive list (see Table 2).

Subordination is generally marked by a signal in the subordinate clause. Subordinators (or more subordinating conjunctions) are the most important device of subordination, particularly for finite clauses. Like prepositions, which they resemble in having a relating function, subordinators forming the core of the class consist of a single word, but there is a larger range of complex subordinators which function, to varying degrees, like a single conjunction. In addition, there is a small class of correlative subordinators, which combine two markers of subordination, one being a subordinator (Quirk et al. 1985, p. 997).

Firstly, they recognize the same conjunctive function of both preposition and subordinator and they added correlative subordinators to the word class. So according to them the subordinators are divided into simple, complex and correlative subordinators, etc. 
Table 2.

\begin{tabular}{|c|c|c|c|c|}
\hline $\begin{array}{c}\text { Simple } \\
\text { subordinators }\end{array}$ & Complex subordinators & $\begin{array}{l}\text { Correlative } \\
\text { subordinators }\end{array}$ & $\begin{array}{c}\text { Marginal } \\
\text { subordinators }\end{array}$ & Other indicators \\
\hline $\begin{array}{l}\text { After, } \\
\text { although, as, } \\
\text { because, } \\
\text { before, } \\
\text { directly, if, } \\
\text { immediately, } \\
\text { lest, like, } \\
\text { once, since, } \\
\text { that, though, } \\
\text { till, unless, } \\
\text { until, } \\
\text { when(ever), } \\
\text { where(ver), } \\
\text { whereas, } \\
\text { whereupon, } \\
\text { while, whilst }\end{array}$ & $\begin{array}{l}\text { Ending with that: but that, in } \\
\text { that, in order that, insofar that, in } \\
\text { the event that, save that, such } \\
\text { that; } \\
\text { ending with optional that: } \\
\text { assuming (that), considering } \\
\text { (that), excepting (that), given } \\
\text { (that), granted (that), granting } \\
\text { (that), provided (that), providing } \\
\text { (that), seeing (that), supposing } \\
\text { (that); except that, for all that, } \\
\text { now that, so that; } \\
\text { ending with as: according as, as } \\
\text { far as, as long as, as soon as, } \\
\text { forasmuch as, inasmuch as, } \\
\text { insofar as, insomuch as; } \\
\text { others: as if, as though, in case }\end{array}$ & $\begin{array}{l}\text { As...so, } \\
\text { as...as, so...as, } \\
\text { such...as, } \\
\text { so/such (that), } \\
\text { less/more(-/er) } \\
\text { than, no } \\
\text { sooner...than/ } \\
\text { when, } \\
\text { barely/hardly/s } \\
\text { carcely... whe } \\
\text { n/than, } \\
\text { the...the, } \\
\text { whether/if...or }\end{array}$ & $\begin{array}{l}\text { Even if, if only; } \\
\text { the moment } \\
\text { (that), every } \\
\text { time (that); } \\
\text { because of the } \\
\text { fact that, due to } \\
\text { the fact that, on } \\
\text { account of the } \\
\text { fact that, in (the) } \\
\text { light of the fact } \\
\text { that, in spite of } \\
\text { the fact that, } \\
\text { regardless of the } \\
\text { fact that; in spite } \\
\text { of the fact/the } \\
\text { news/ your } \\
\text { report/my belief }\end{array}$ & $\begin{array}{l}\text { Wh-elements: who, } \\
\text { whom, whose, which, } \\
\text { when, where, what, } \\
\text { why, how, whoever, } \\
\text { whomever, whichever, } \\
\text { wherever, } \\
\text { whenever, whatever, } \\
\text { however, whosoever, } \\
\text { whomsoever, } \\
\text { wheresoever, } \\
\text { whatsoever, } \\
\text { howsoever; the relative } \\
\text { pronoun that; the } \\
\text { subject-operator } \\
\text { inversion; the absence } \\
\text { of a finite verb }\end{array}$ \\
\hline
\end{tabular}

(Quirk et al., 1985, pp. 998-1007)

Obviously Quirk et al. (1985) make the class more inclusive and complete.

Martin (2000) sub-classifies the subordinating conjunctions from the perspective of meaning.

Table 3.

\begin{tabular}{ll}
\hline meaning & Subordinating conjunctions \\
\hline Time & After, as, as long as, before, since, until, when, while \\
Place & In the same place as, where, wherever \\
Reason & As, because, since \\
Manner & As if, as though \\
Contrast & Although, despite the fact that, even though, though, while \\
Condition & As long as, given that, if, provided that, unless \\
Purpose & In order that, so that \\
Result & So, so that \\
\hline Martin, 2000,
\end{tabular}

(Martin, 2000, p. 423)

Martin (2000) also studies the polysemy of some conjunctions, like since, which could express meanings of both time and reason and subdivides the conjunctions of time, according to meaning again, into 8 types: simultaneous events, non-simultaneous, immediate sequence, duration, no duration, "time before", "time after", extending to the present.

Making grammatical classification according to meaning might be easy for readers to follow, but difficult to distinguish from each other. It always seems to be just a list, easy to find exceptions and not exhaustive.

Downing and Locke (2002) actually subcategorize the subordinators, which serves to indicate the dependent status of clauses together with its circumstantial meaning, both formally and semantically. 
Table 4.

\begin{tabular}{|c|c|c|c|c|}
\hline \multirow[t]{2}{*}{ Simple conj. } & \multirow{2}{*}{$\begin{array}{l}\text { Conjunctive } \\
\text { groups }\end{array}$} & \multicolumn{3}{|c|}{ Complex conjunctions } \\
\hline & & Derived from verbs & $\begin{array}{c}\text { Containing a } \\
\text { noun }\end{array}$ & Adverbial \\
\hline $\begin{array}{l}\text { When, whenever, } \\
\text { where, wherever, } \\
\text { because, if, } \\
\text { unless, until, } \\
\text { while, as, } \\
\text { although }\end{array}$ & $\begin{array}{l}\text { As if, as though, } \\
\text { even if, even } \\
\text { though, even } \\
\text { when, soon after, } \\
\text { no sooner }\end{array}$ & $\begin{array}{l}\text { Provided (that), granted } \\
\text { (that), considering } \\
\text { (that), seeing (that), } \\
\text { suppose (that), } \\
\text { supposing (that), so } \\
\text { (that) }\end{array}$ & $\begin{array}{l}\text { In case, in the } \\
\text { event that, to } \\
\text { the extent that, } \\
\text { in spite of the } \\
\text { fact that, the } \\
\text { day, the way }\end{array}$ & $\begin{array}{l}\text { So/as long as, } \\
\text { as soon as, } \\
\text { so/as far as, } \\
\text { much as, now } \\
\text { (that) }\end{array}$ \\
\hline
\end{tabular}

(Downing \& Locke, 2002, p. 292)

Table 5 .

\begin{tabular}{|c|c|c|}
\hline Time & Contingency & Manner \\
\hline $\begin{array}{l}\text { As (simultaneous), after (anteriority) eventive, } \\
\text { before (potential event), since (starting point } \\
\text { of duration), when (eventive), when (potential } \\
\text { event), whenever (potential/ eventive), while } \\
\text { (time-simultaneous), now that (time-reason), } \\
\text { as soon as (eventive), the day (eventive), the } \\
\text { moment (potetial), until (duration+end point) }\end{array}$ & $\begin{array}{l}\text { As far as (to the extent that...), in so far as (to } \\
\text { the degree that), if (open condition), if (rhetorical } \\
\text { conditional), unless (negative condition), as long } \\
\text { as (condition), provided that (condition), before } \\
\text { (implied condition), although/though } \\
\text { (concession), while (concession), much as } \\
\text { (concession), as (reason), because (reason), since } \\
\text { (reason), so that (purpose), in order that } \\
\text { (purpose), so that (result) }\end{array}$ & $\begin{array}{c}\text { As if/as } \\
\text { though, the } \\
\text { way } \\
\text { (manner) }\end{array}$ \\
\hline
\end{tabular}

Causal, concessive, conditional and resultative clauses depend on the hearer's knowledge of the world, which provides an inferential link between the content of the main clause and that of the dependent clause (Downing $\&$ Locke, 2002).

And they talk about pragmatic conjunctions and speech acts. Their classification according to both form and meaning seem fairly inclusive than Quirk et al.'s, even include the latter's marginal subordinators. Further more, to talk about conjunctions pragmatically is challenging. And as is shown in the table below, they have similar but more detailed subclass labels for each of the time conjunctions than Martin (2000). The question is they use different terms and did not explain how to distinguish these subclasses of time conjunction or subordinator.

However, Biber et al. (2000) first make a distinction between words introducing relative clauses and the ones introducing other clauses, such as subject, object and complement clause etc. and use a different term, relativizer, for those words introducing relative clauses and compare relativizers with subordinators. They are similar in that both introduce dependent clauses, but they differ from each other in that relativizers have a syntactic role as clause element or part of a clause element and the clauses relativizer introduce are generally post modifiers of preceding noun phrases, on which the choice of relativizers depends while subordinators have a purely syntactic role, not roles as subject, object, adverbial, etc.. Consider the following examples:

[1] a. That I need help is clear.

b. I know that it's genuine.

c. The only issue is whether he was lying.

d. They complained because we didn't finish he job this week.

e. The secretary wrote to all the members who were absent from the meeting.

According to Biber et al. (2000), who in [e] should be relativizer. This distinction is reasonable and necessary in that a relative clause, such as the underlined part in [e] can't make the whole clause a complex one, whereas the other four examples above are complex clauses. So from the perspective of distinguishing simple clauses from complex ones this distinction between relativizer and subordinator is quite useful. So relative clauses are different from subordinate clauses though there is subordination between the relative clauses and the NPs that are modified by them. That is to say, relative clauses are not subordinate clauses like the underlined clauses in [1a], [1b], [1c] and [1d]. 
Biber et al. (2000) also propose another term, complementizer, for those subordinators, if, that, whether and whwords, introduce complement clauses (or nominal clauses). These subordinators have little meaning apart from marking structural dependency (p.85). However, wh- words do have meaning and, like relativizers mentioned above, they have syntactic roles as clause elements. In addition, if whether in [1c] is a complementizer, what about that in [1a] and [1b] since it also has little meaning and the same grammatical role of marking structural dependency as whether? Are they still complementizer when they introduce subject and object clauses? It is also not desirable to invent the terms of subjectizer or objectizer, which will result in too much overlapping. Actually Biber et al. (2000) have realized the overlap between subordinators and other word classes and talked about the most extreme case of overlap of that as complementizer, relativizer, subordinator, adverb, determinative and pronoun.

Table 6.

\begin{tabular}{|c|c|c|c|c|}
\hline \multicolumn{3}{|c|}{ Major subordinator } & complex & \multirow{3}{*}{\begin{tabular}{l}
\multicolumn{1}{c}{ correlative } \\
Simple+adv.: \\
If...then. \\
although...yet, \\
as...as; degree \\
element: as...as, \\
more than, so...that, \\
the...the
\end{tabular}} \\
\hline $\begin{array}{l}\text { (1)Introducing } \\
\text { adverbial clause }\end{array}$ & $\begin{array}{l}\text { (2)Introducing } \\
\text { degree clause }\end{array}$ & $\begin{array}{l}\text { (3)Introducing } \\
\text { complement }\end{array}$ & $\begin{array}{l}\text { As: according as, as far as, } \\
\text { as long as, as soon as }\end{array}$ & \\
\hline \multirow[t]{2}{*}{$\begin{array}{c}\text { After, as, } \\
\text { because, if, } \\
\text { since, (al)though, } \\
\text { whether, while, } \\
\text { etc. }\end{array}$} & As, that, than & $\begin{array}{l}\text { clause(or nominal } \\
\text { clause): } \\
\text { complementizer }\end{array}$ & $\begin{array}{l}\text { That: given (that), } \\
\text { granted/granting (that), on } \\
\text { condition (that), provided } \\
\text { (that); directly (that), } \\
\text { immediately (that), now } \\
\text { (that), the moment (that); but } \\
\text { that. Except (that), in that, in } \\
\text { order that, so (that), such } \\
\text { that }\end{array}$ & \\
\hline & & & $\begin{array}{l}\text { Others: as if, as though, even } \\
\text { if, even though, in case, no } \\
\text { matter (+wh- word) }\end{array}$ & \\
\hline
\end{tabular}

(Biber et al., 2000, p. 85)

Huddleston and Pullum (2005) argue that there are three subordinators, namely that, whether and if indicating interrogation. They put words in [i] and [iia] in the following table into the class of preposition.

Table 7.

\begin{tabular}{lrl}
\hline i & & After, before, since, till, until \\
\hline ii & a & Although, because, if(c), lest, provided, though, unless \\
& b & If(i), that, whether
\end{tabular}

(Huddleston \& Pullum, 2005, p. 129)

They have good reasons for doing this because they have extended the membership of the class of preposition class by modifying the usage of prepositions. They think that it is not well justified that prepositions should have NP complements by giving the examples as follows:

Table 8 .

\begin{tabular}{llll}
\hline & Type of complement & Before AS HEAD & Know AS HEAD \\
\hline i & NP & We left before the last act. & We know the last act. \\
ii & CLAUSE & That was before he died. & I know he died. \\
iii & NO COMPLEMENT & I had seen her once before. & Yes, I know. \\
\hline
\end{tabular}

(Huddleston \& Pullum, 2005, p. 129) 
In [i] the complement of before or know (marked by double underline) is an NP; in [ii] it is a subordinate clause; and in [iii] there is no complement. Everyone agrees that this difference in the complements has no bearing on the classification of know: it is a verb in all three examples. Know happens to be a verb that licenses either an $\mathrm{NP}$ or a clause as complement, and where the complement is optional. However, traditional grammar treats before in a completely different way. It is treated as a preposition in [i], a subordinating conjunction in [ii], and an adverb in [iii], which is unnecessary complication. It is much simpler to give before a uniform analysis just as know is a verb in all three. So before is a preposition, not a subordinator even when the complement is a clause. Thus the boundaries between prepositions and subordinators are redrawn.

For words in [iia] Table 1, they reassign them to the preposition class as well. The main reason for doing this is that words in [iia] are not grammatical markers of subordination. They have independent meaning, and it is by virtue of this meaning that we interpret the clauses after them as adjuncts of time and reason respectively. So in the above example [1d] because is a preposition because it has independent meaning of reason we use it to show the relationship between they complained and we didn't finish the job this week. In contrast, in [1a], [1b] and $[1 \mathrm{c}]$, that and whether are purely grammatical markers of subordination.

To sum up, traditional definitions and classifications treat relative clauses as subordinate clause and thus markers introducing relative clauses are also accounted as subordinators. However, Biber et al. (2000) put forward the term relativizer to distinguish markers introducing relative clauses and subordinate clauses. Complementizer focuses on the function of the subordinate clause markers, having little meaning but only grammatical role of marking structural dependency. Huddleston and Pullum (2005) study whether markers of subordinate clauses are all subordinators. They find that some markers of subordinate clauses are not subordinators but prepositions and redraw the boundaries between the preposition class and the subordinator class and leave a small subordinator class-that, whether and if indicating interrogation.

\section{Augumentation}

Traditional way of defining subordinators is not clear on two points: one is whether relative clauses should be treated as subordinate clause; whether there are any difference among all markers of subordinate clauses, including subject, object, complement and adverbial clauses. Are they all subordinators or should they be differentiated?

For the first question, Biber et al. (2000) have given very good reasons when distinguishing relativizers and subordinators that relative clauses usually depend on the preceding NPs while subordinate clause are dependent on other clauses. Thus relative clauses are not subordinate clause and it is necessary to name the markers of relative clauses relativizers, different from subordinators, marking the relationship of dependency between two clauses. And they also realize that among subordinators some, such as that, whether and if which indicates interrogation, are different from other subordinators in that they have little meaning apart from marking structural dependency and name them complementizers. But actually when that, whether or if introduces subject or object clauses they function the same as when they introduce complement clauses. So it may be strange and misleading to call them complementizers when they actually introduce subject or object clauses.

For the second question, traditional grammar treats all markers of subordinate clauses as subordinators. However, Huddleston and Pullum (2002) think differently. They not only recognize the differences between grammatical markers of subordinate clauses and the others but also put the grammatical markers into subordinators and others into the preposition, adverbial classes with good reasons.

The inaccuracy of the traditional classifications of subordinators should be attributable to two factors: the improper definitions and word class division; the perspectives for classifying word classes. The first factor has been explained in detail in the above mentioned. The second factor refers to the perspectives of form and meaning. To make classifications in terms of form may be very clear and neat. For example, Quirk et al. (1985), Carter and McCarthy (2006) classify subordinators according to how many words there are in a subordinator. If one word, it is simple subordinator; two or more, complex. It is easy to teach and grasp. However, this classification can't give any clue on how to use the words. Subordinators are classified for the sake of classification. To make classifications in terms of meaning can provide learners with some clues on when to use the words. For example, Martin Parrot (2000) classifies subordinators into time, place, reason, etc to tell teachers and learners when to use which subordinators to express semantic relationship between clauses. However, Downing and Locke (2002) use some different terms, like time, contingency, manner, etc. and have different division of subordinators. Because, since, in order (that), etc are included in the category of contingency. From this difference in the division of words, personal interpretation of the meaning of subordinators can be seen playing a vital part. Actually Downing and Locke (2002) also talk about some clauses, such as causal, concessive, 
conditional and resultative clauses depend on the hearer's knowledge of the world, which provides an inferential link between the content of the main clause and that of the dependent clause (p. 294). And they go further to talk about conjunctions from pragmatic point of view. Conjunctions express the semantic relationship between the units they connect, reflecting the speaker's view of the connection between states of affairs in the world (p. 294). Defining subordinators in terms of meaning will lead, to some extent, to subjectivity. No wonder there are different divisions in terms of meaning. Grammar is autonomous and independent of meaning (Chomsky, 2002, p.17). To make classifications in terms of function may be complete and useful to teachers and learners because syntactic functions are limited in number and functions will give teachers and learners useful clues on how to use the words directly.

\section{Conclusion}

In conclusion, English subordinators for finite clauses should be defined in terms of syntactic function as grammatical markers of subordinate clauses. That is, words marking other dependent status of clauses are not subordinate clauses, for example, markers introducing relative clauses are not subordinators because relative clauses. And marks for other clauses, subject, object, complement and adverbial clauses, are not all subordinators. Only the grammatical markers of these four kinds of clauses are subordinators. In this case, a small class of subordinators is left---that, whether and if that indicates interrogation. And the boundaries of prepositions and subordinators are redrawn with good reasons so that the two classes are more coherent and distinct from other classes with less overlapping.

\section{Acknowledgments}

Thanks to Professor Guoha Chen in BFSU, under whose help and influence the author found the idea of word class definition and classification.

\section{References}

Biber, D., Stig, J., Geoffrey, L., Susan, C., \& Edward, F. (2000). Longman Grammar of Spoken and Written English. Beijing: Foreign Language Teaching and Research Press.

Carter, R., \& McCarthy, M. (2006). Cambridge Grammar of English: A Comprehensive Guide. Cambridge: Cambridge University Press.

Downing, A., \& Philip, L. (2002). A University Course in English Grammar. London: Routledge.

Herbert, F. W. S. (1976). Which That Language. Linguistic Society of America, 52(3), 584-610.

Huddleston, R., \& Pullum, G. K. (2005). A Student's Introduction to English Grammar. http://dx.doi.org/10.1017/cbo9780511815515

Jackson, S., David, T., \& Thomas, B. (2005). Separating similar effects of conjunction and intonation in the resolution of lexical ambiguity. Studia Linguistica, 59(2), 259-278. http://dx.doi.org/10.1111/j.1467-9582.2005.00129.x

Joan, B. (1973). Syntax of the comparative clause construction in English. Linguistic Inquiry, 9, 331-91.

Johan, V. D. A. (1985). "Relative That": A Centennial Dispute. Journal of Linguistics, 21(1), 149-179.

John, R. R. (1986). Infinite Syntax! New York, NY: Ablex.

Parrott, M. (2000). Grammar for English Language Teachers. Cambridge: Cambridge University Press.

Quirk, R., Sidney, G., Geoffrey, L., \& Jan, S. (1985) A Comprehensive Grammar of the English Language. London: Longman.

Ralph, B. L. (1967). The English "Conjunctions". American Speech, 42(3), 163-177. http://dx.doi.org/10.2307/453346

Richard, M. S. (1974). Subordinate Clauses and Asymmetry. English Journal of Linguistics, 10(2), 235-269. http://dx.doi.org/10.1017/s0022226700006083

Sanz, R. L. (2003). The translation of tourist literature: The case of connectors. Multilingua, 22(3), 291-308. http://dx.doi.org/10.1515/mult.2003.015

Stevick, E. W. (1950). The "Deferred Preposition". American Speech, 25(3), 211-214 http://dx.doi.org/10.2307/453754

Vivian, S. P. (1950). The Classification of the Conjunction "For". American Speech, 25(2), 112-117. http://dx.doi.org/10.2307/453540 


\section{Copyrights}

Copyright for this article is retained by the author(s), with first publication rights granted to the journal.

This is an open-access article distributed under the terms and conditions of the Creative Commons Attribution license (http://creativecommons.org/licenses/by/3.0/). 